
with coronary artery chronic total occlusion. Journal of Education, Health and Sport. 2020;10(6):275-285. eISSN 2391-8306. DOI http://dx.doi.org/10.12775/JEHS.2020.10.06.030

https://apcz.umk.pl/czasopisma/index.php/JEHS/article/view/JEHS.2020.10.06.030

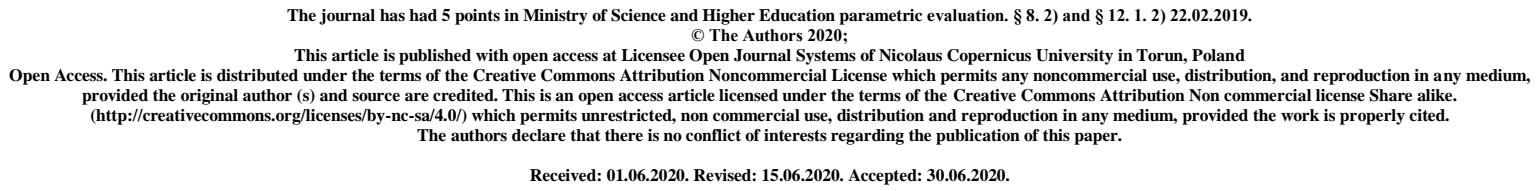

\title{
Myocardial blood flow assessment with myocardial perfusion scan in patients with coronary artery chronic total occlusion
}

\author{
Magdalena Jańczyk (1), Ilona Samek (1), dr n. med. Marcin Pachowicz (2)
}

1) Students Scientific Association at the Chair and Department of Nuclear Medicine, Medical University of Lublin

2) Chair and Department of Nuclear Medicine, Medical University of Lublin

*Address for correspodence: Smolniki 7/12, 18-520 Stawiski, telephone number: 662237472, e-mail address: magdajanczyk7@gmail.com

\section{ORCID ID and e-mail:}

Magdalena Jańczyk: https://orcid.org/0000-0002-4948-9463; magdajanczyk7@gmail.com Ilona Samek: https://orcid.org/0000-0002-5538-5396; samekilona@gmail.com Marcin Pachowicz: https://orcid.org/0000-0002-0714-2170; marcin.pachowicz.md@gmail.com 


\begin{abstract}
Introduction and purpose: Coronary artery disease (CAD) is a leading cardiological problem in modern society. A special form of CAD is the Chronic Total Occlusion (CTO), which affects about $20 \%$ of visible coronary artery lesions. The aim of the study is to present the role of myocardial perfusion scintigraphy performed on patients with CTO, and scintigraphic findings in these patients.

Material and method: It was a retrospective study. We analized studies in patients with CTO reported in medical history. We included studies performed between 2016 and 2019. 119 cases were found with the majority of men $(\mathrm{M}=95, \mathrm{~W}=24)$. The patients' mean age was 65 years $(\mathrm{M}=65, \mathrm{~W}=66)$. In order to assess ischemia in these patients, the stress test was applied by means of physical exercise (cycloerometer) or pharmacological test. If patient's clinical condition did not allow a stress test, only a rest test was performed.

Results: In the analyzed group the most common occluded vessel was the right coronary artery $(59 \%)$. In this case, mean ischaemia was found to cover $18 \%$ of the myocardium. The second most frequent obstructed vessel was the circumflex (16\%) with ischaemia of $15 \%$. The next artery was left anterior descending artery with ischaemia of $30 \%$ and other vessel $-7 \% .9$ patients had more than one vessel closed.
\end{abstract}

Conclusions: Myocardial perfusion imaging helps to choose optimal treatment in patients with CTO.

Key words: heart; scintigraphy; perfusion; CTO

\title{
Introduction and purpose
}

Recently, there has been a significant improvement in diagnostic and therapeutic procedures in the field of coronary artery disease (CAD), which improve the patients' prognosis and quality of life. A special form of CAD is Chronic Total Occlusion (CTO) of a coronary vessel. According to current definitions, CTO is diagnosed when complete elimination of coronary artery blood flow, lasting more than 3 months, is observed [1,2]. There are various diagnostic methods for CTO, including coronary angiography or computed tomography. The CTO accounts for about $20 \%$ of all lesions found in these studies [1, 2, 3].

Myocardial perfusion scan (MPS) is performed in order to clarify the presence of ischemia. The SPECT result allows to identify patients with a high risk of myocardial infarction or death [4]. It is performed in order to qualify patients for the appropriate type of treatment. It can also be used to evaluate the results of the selected therapy or procedure. It allows to evaluate the regional myocardial blood flow, which is illustrated by the regional uptake of a radiolabelled substance (for example 99mTc-sestamibi). If there are no contraindications, the stress and optionally rest studies are performed. Treadmill or cycloergometer can be used. If the patient is unable to exercise, the pharmacological stress is applied, most commonly with drugs dilating the vessels (e.g. adenosine, dipyridamole, regadenoson) or increasing the cardiomyocytes' oxygen demand (e.g. dobutamine) [5]. The data are collected with single photon emission computed tomography and then processed. Cross-sections are created and compared in three planes for both stress and rest conditions. Reversible ischaemia is presented as a decrease radiotracer uptake in stress test and its normal distribution in rest conditions. Perfusion absence in both tests indicates fixed perfusion defect which may suggest the 
presence of CTO or coronary artery critical stenosis [6]. Studies suggest that the localization of the occluded vessel may be a key factor affecting the life expectancy of patients.

CTO treatment methods include Percutaneous Coronary Intervention (PCI) and Optimal Medical Treatment (OMT). However, currently only 5\% of patients undergo revascularization because the high risk of complications and no clear advantage of PCI over pharmacological treatment has been demonstrated [8].

The PCI procedure involves the insertion of a balloon catheter into the narrowed coronary artery through the skin in order to dilate its lumen with possible stent implantation. Its efficacy is significantly influenced by, among others, histopathological differentiation of atherosclerotic plaque core in terms of calcification and neoangiogenesis [3,4]. The hard structure of the embolus core makes it difficult to conduct the guide, which increases the risk of numerous complications, e.g. perforation and dissection of the vessel. The operator's experience is also extremely important. When it is performed in highly specialized centers, its effectiveness is over $90 \%$ [9]. Most of the possible complications are successfully managed during the procedures, but the percentage of deaths $(1.3 \%)$ is much higher in comparison with the procedures of unobstructed vessels [10].

\section{Purpose}

The aim of the study is to present the application and role of the MPS in patients with CTO.

\section{Material and methods}

The paper was retrospective in nature. We analyzed the results of MPS in patients in who available medical documentation indicated the presence of CTO of at least one coronary artery. The study covered the period from 01.01.2016 to 28.02.2019.

Out of 2015 patients who underwent the MPS at the indicated time, 119 patients (5.9\%) had a CTO, including 95 men and 24 women.

The stress study was performed after intravenous injection of $555 \mathrm{MBq}$ (megabequerels) of ${ }^{99 \mathrm{~m}}$ Tc-sestamibi (radioactive agent most commonly used for MPS). Administered activity for rest study was $370 \mathrm{MBq}$. All exams were performed using Symbia T16 SPECT/CT gammacamera, and they were processed and evaluated with dedicated software including Corridor 4DM (Invia, Ann Arbor Michigan).

The ischemia degree was expressed by percentage of the left ventricle myocardium involved and it was derived from automatic calculation utilizing data base from the Corridor software. Left ventricle enlargement was determined by cut-off values estimated for this software as well (165 $\mathrm{ml}$ for men and $103 \mathrm{ml}$ for women).

According to current guidelines reversible ischemia of at least $10 \%$ indicates necessity of invasive treatment. Thus, we assumed total ischemia $\leq 5 \%$ insignificant - patients were treated as without significant ischemia. Reversible ischemia $\leq 5 \%$ was also considered insignificant patients were treated as fixed defects only. 


\section{Results}

\section{MEN}

The mean age of men was 65 years (38-82 years), 54 patients (57\%) had CTO of right coronary artery (RCA), 12 patients (13\%) had CTO of left anterior descending artery (LAD), 17 patients $(18 \%)$ had CTO of circumflex branch $(\mathrm{Cx}), 7$ patients $(7 \%)$ had two coronary arteries, 5 patients $(5 \%)$ had one of the smaller coronary arteries (diagonal branch - DIA, marginal branch - OM) closed.

The findings are summarized in table 1. Among patients with CTO of two arteries in all patients CTO RCA was found, in 2 patients with CTO LAD and in 5 patients with CTO Cx.

\begin{tabular}{|c|c|c|c|c|c|}
\hline & RCA & LAD & $C x$ & other & $\begin{array}{c}2 \\
\text { arteries }\end{array}$ \\
\hline $\begin{array}{c}\text { total number of } \\
\text { patients }\end{array}$ & 54 & 12 & 17 & 5 & 7 \\
\hline $\begin{array}{c}\text { cycloergometer } \\
\text { stress test (no of pts) }\end{array}$ & 29 & 7 & 15 & 5 & 0 \\
\hline $\begin{array}{c}\text { combined stress test } \\
\text { (no of pts) }\end{array}$ & 11 & 2 & 2 & 0 & 0 \\
\hline $\begin{array}{c}\text { dipiridamol only } \\
\text { stress test (no of pts) }\end{array}$ & 1 & 0 & 0 & 0 & 1 \\
\hline $\begin{array}{c}\text { regadenoson test (no } \\
\text { of pts) }\end{array}$ & 0 & 0 & 0 & 0 & 0 \\
\hline $\begin{array}{c}\text { gated data } \\
\text { unavailable (no of } \\
\text { pts) }\end{array}$ & 4 & 1 & 1 & 0 & 0 \\
\hline $\begin{array}{l}\text { LV enlargement (no } \\
\text { of pts) }\end{array}$ & 13 & 4 & 4 & 0 & 5 \\
\hline $\begin{array}{c}\text { mean LV end } \\
\text { diastolic volume (ml) }\end{array}$ & 153 & 185 & 152 & 133 & 235 \\
\hline $\begin{array}{c}\text { maximum LV end } \\
\text { diastolic volume (ml) }\end{array}$ & 328 & 424 & 383 & 152 & 382 \\
\hline $\begin{array}{c}\text { mean LV muslce } \\
\text { mass }(\mathrm{g})\end{array}$ & 174 & 195 & 171 & 165 & 215 \\
\hline $\begin{array}{c}\text { maximum LV muscle } \\
\text { mass }(\mathrm{g})\end{array}$ & 287 & 316 & 279 & 176 & 275 \\
\hline $\begin{array}{c}\text { mean LV ejection } \\
\text { fraction (\%) }\end{array}$ & 62 & 63 & 62 & 67 & 44 \\
\hline $\begin{array}{c}\text { minimal LV ejection } \\
\text { fraction (\%) }\end{array}$ & 22 & 39 & 26 & 59 & 31 \\
\hline $\begin{array}{l}\text { normal perfusion } \\
\text { (no of pts) }\end{array}$ & 4 & 1 & 4 & 1 & 0 \\
\hline
\end{tabular}




\begin{tabular}{|c|c|c|c|c|c|}
\hline $\begin{array}{l}\leq 5 \% \text { ischemia (no of } \\
\text { pts) }\end{array}$ & 13 & 0 & 4 & 2 & 0 \\
\hline $\begin{array}{c}>5 \% \text { fixed ischemia } \\
\text { only (no of pts) }\end{array}$ & 18 & 3 & 5 & 2 & 0 \\
\hline $\begin{array}{c}>5 \% \text { reversible } \\
\text { ischemia (no of pts) }\end{array}$ & 8 & 5 & 4 & 0 & 1 \\
\hline $\begin{array}{c}\text { mean total ischemia } \\
(\%)\end{array}$ & 18 & 30 & 26 & 13 & 23 \\
\hline $\begin{array}{l}\text { maximum total } \\
\text { ischemia (\%) }\end{array}$ & 37 & 49 & 50 & 16 & 23 \\
\hline $\begin{array}{c}\text { mean fixed ischemia } \\
(\%)\end{array}$ & 12 & 20 & 18 & 13 & 14 \\
\hline $\begin{array}{l}\text { maximum fixed } \\
\text { ischemia (\%) }\end{array}$ & 37 & 43 & 39 & 16 & 14 \\
\hline $\begin{array}{c}\text { mean reversible } \\
\text { ischemia (\%) }\end{array}$ & 5 & 26 & 17 & 0 & 9 \\
\hline $\begin{array}{c}\text { maximum reversible } \\
\text { ischemia (\%) }\end{array}$ & 15 & 48 & 22 & 0 & 9 \\
\hline $\begin{array}{l}\text { rest only available } \\
\text { (no of pts) }\end{array}$ & 13 & 3 & 0 & 0 & 6 \\
\hline $\begin{array}{c}\text { rest only mean total } \\
\text { ischemia (\%) }\end{array}$ & 13 & 3 & 0 & 0 & 6 \\
\hline $\begin{array}{l}\text { rest only maximum } \\
\text { total ischemia (\%) }\end{array}$ & 51 & 70 & 0 & 0 & 65 \\
\hline
\end{tabular}

Table 1. Ischemia and left ventricle function in men with CTO. no of pts - number of patients; LV - left ventricle

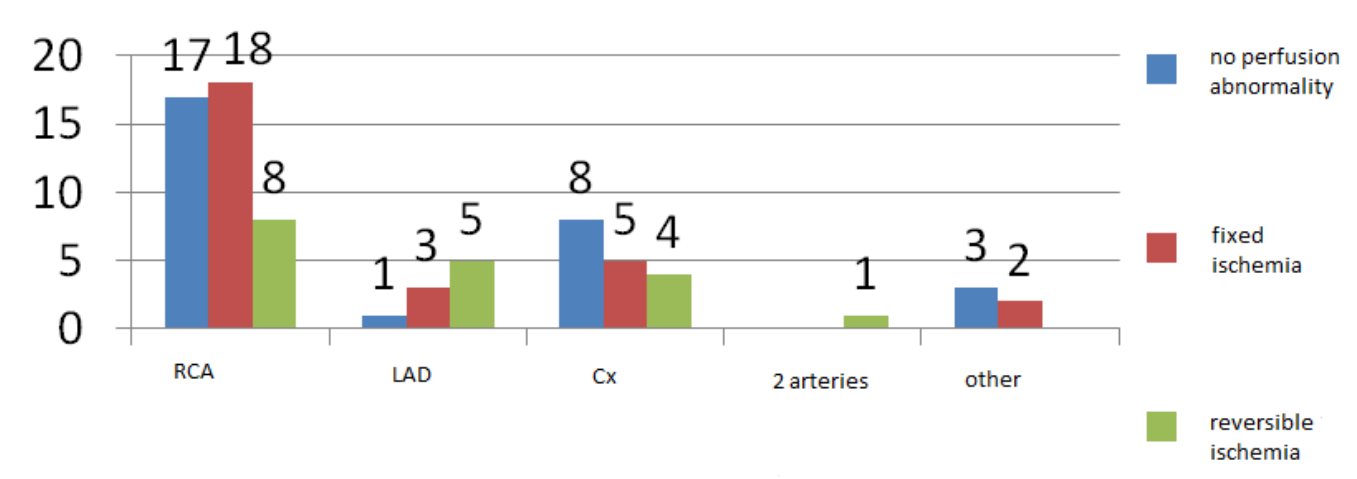

Chart 1. Ischemia characterization in men with CTO part 1.

Number of patients with normal perfusion or ischemia $\leq 5 \% ;>5 \%$ fixed only ischemia and $>5 \%$ reversible ischemia. 


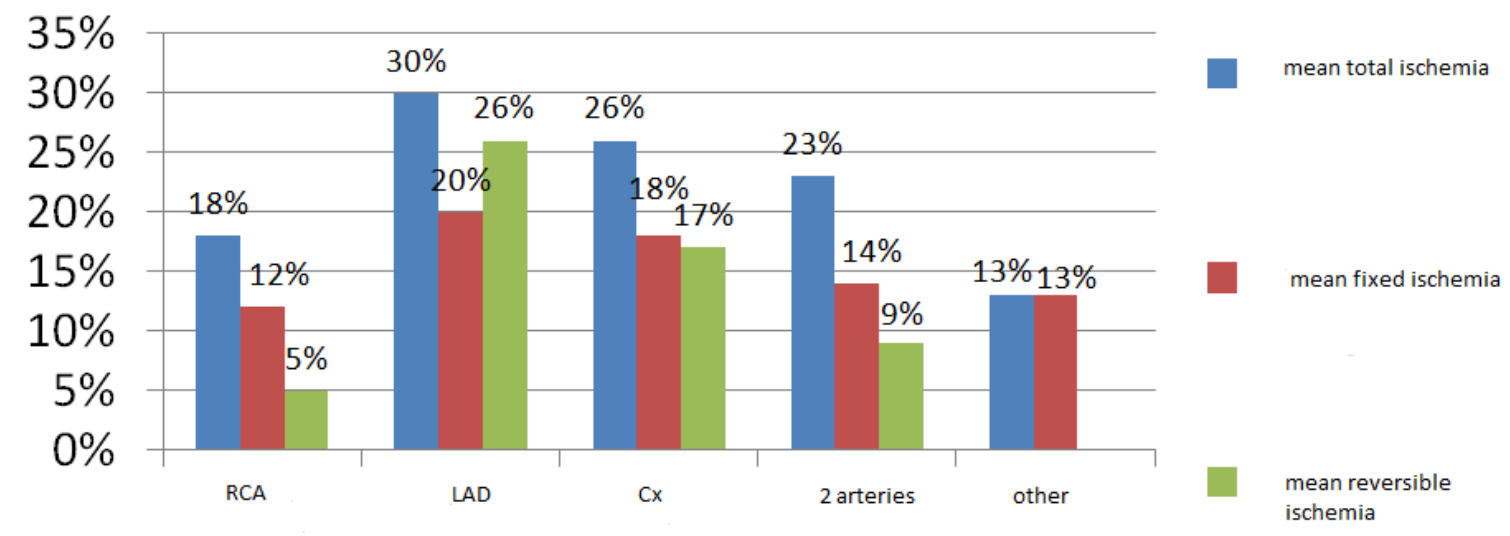

Chart 2. Ischemia characterization in men with CTO part 2.

Ischemia percentage in particular coronary artery occluded.

Most important findings:

- $\quad$ Left ventricle enlargement was found in 26 patients $(27 \%)$; the greatest enlargement was found in case of LAD CTO and CTO of two arteries.

- Reversible ischemia is predominantly found in patients with LAD CTO in case of other arteries normal perfusion or fixed defects dominate,

- $\quad$ The highest mean ischemia was also found in patients with LAD CTO,

- In the most numerous group with RCA CTO normal perfusion or insignificant ischemia was found in nearly $40 \%$ of patients. 


\section{WOMEN}

The average age of women was 66 years (48-82 years). In 16 patients (67\%) CTO RCA was found, in 4 patients (17\%) CTO LAD, in 2 patients (8\%) CTO Cx, in 2 patients (8\%) closure of two coronary arteries. However, no closure of one of the smaller coronary arteries was observed.

The findings are summarized in table 2. In patients with CTO of two arteries in both patients CTO LAD was found, in 1 patient in combination with CTO RCA, in the second - in combination with CTO another smaller coronary artery.

\begin{tabular}{|c|c|c|c|c|c|}
\hline & RCA & LAD & $C x$ & other & $\begin{array}{c}2 \\
\text { arteries }\end{array}$ \\
\hline total no of patients & 16 & 4 & 2 & 0 & 2 \\
\hline $\begin{array}{c}\text { cycloergometer (no } \\
\text { of pts) }\end{array}$ & 11 & 4 & 2 & 0 & 0 \\
\hline combined (no of pts) & 2 & 0 & 0 & 0 & 1 \\
\hline $\begin{array}{c}\text { dipiridamol only (no } \\
\text { of pts) }\end{array}$ & 1 & 0 & 0 & 0 & 0 \\
\hline $\begin{array}{c}\text { regadenoson (no of } \\
\text { pts) }\end{array}$ & 1 & 0 & 0 & 0 & 0 \\
\hline $\begin{array}{c}\text { gated data } \\
\text { unavailable (no of } \\
\text { pts) }\end{array}$ & 1 & 0 & 0 & 0 & 1 \\
\hline $\begin{array}{l}\text { LV enlargement (no } \\
\text { of pts) }\end{array}$ & 4 & 1 & 0 & 0 & 1 \\
\hline $\begin{array}{c}\text { mean LV end } \\
\text { diastolic volume (ml) }\end{array}$ & 98 & 88 & 72 & 0 & 118 \\
\hline $\begin{array}{c}\text { maximum LV end } \\
\text { diastolic volume (ml) }\end{array}$ & 141 & 116 & 82 & 0 & 151 \\
\hline $\begin{array}{c}\text { mean LV muslce } \\
\text { mass }(\mathrm{g})\end{array}$ & 134 & 129 & 119 & 0 & 154 \\
\hline $\begin{array}{c}\text { maximum LV muscle } \\
\text { mass }(\mathrm{g})\end{array}$ & 153 & 150 & 130 & 0 & 189 \\
\hline $\begin{array}{c}\text { mean LV ejection } \\
\text { fraction (\%) }\end{array}$ & 75 & 79 & 76 & 0 & 54 \\
\hline $\begin{array}{c}\text { minimal LV ejection } \\
\text { fraction (\%) }\end{array}$ & 59 & 70 & 70 & 0 & 34 \\
\hline $\begin{array}{c}\text { normal perfusion } \\
\text { (no of pts) }\end{array}$ & 5 & 1 & 0 & 0 & 0 \\
\hline $\begin{array}{l}\leq 5 \% \text { ischemia (no of } \\
\text { pts) }\end{array}$ & 3 & 0 & 0 & 0 & 0 \\
\hline
\end{tabular}




\begin{tabular}{|c|c|c|c|c|c|}
\hline $\begin{array}{c}>5 \% \text { fixed ischemia } \\
\text { only (no of pts) }\end{array}$ & 2 & 1 & 1 & 0 & 0 \\
\hline $\begin{array}{c}>5 \% \text { reversible } \\
\text { ischemia (no of pts) }\end{array}$ & 5 & 3 & 1 & 0 & 1 \\
\hline $\begin{array}{c}\text { mean total ischemia } \\
(\%)\end{array}$ & 11 & 17 & 14 & 0 & 58 \\
\hline $\begin{array}{l}\text { maximum total } \\
\text { ischemia (\%) }\end{array}$ & 41 & 37 & 20 & 0 & 58 \\
\hline $\begin{array}{c}\text { mean fixed ischemia } \\
(\%)\end{array}$ & 5 & 7 & 15 & 0 & 1 \\
\hline $\begin{array}{l}\text { maximum fixed } \\
\text { ischemia (\%) }\end{array}$ & 16 & 17 & 29 & 0 & 1 \\
\hline $\begin{array}{c}\text { mean reversible } \\
\text { ischemia (\%) }\end{array}$ & 5 & 10 & 1 & 0 & 57 \\
\hline $\begin{array}{c}\text { maximum reversible } \\
\text { ischemia (\%) }\end{array}$ & 37 & 20 & 1 & 0 & 57 \\
\hline $\begin{array}{l}\text { rest only available } \\
\text { (no of pts) }\end{array}$ & 1 & 0 & 0 & 0 & 1 \\
\hline $\begin{array}{c}\text { rest only mean total } \\
\text { ischemia (\%) }\end{array}$ & 5 & 0 & 0 & 0 & 5 \\
\hline $\begin{array}{l}\text { rest only maximum } \\
\text { total ischemia (\%) }\end{array}$ & 5 & 0 & 0 & 0 & 5 \\
\hline
\end{tabular}

Table 2. Ischemia and left ventricle function in women with CTO. no of pts - number of patients; LV - left ventricle

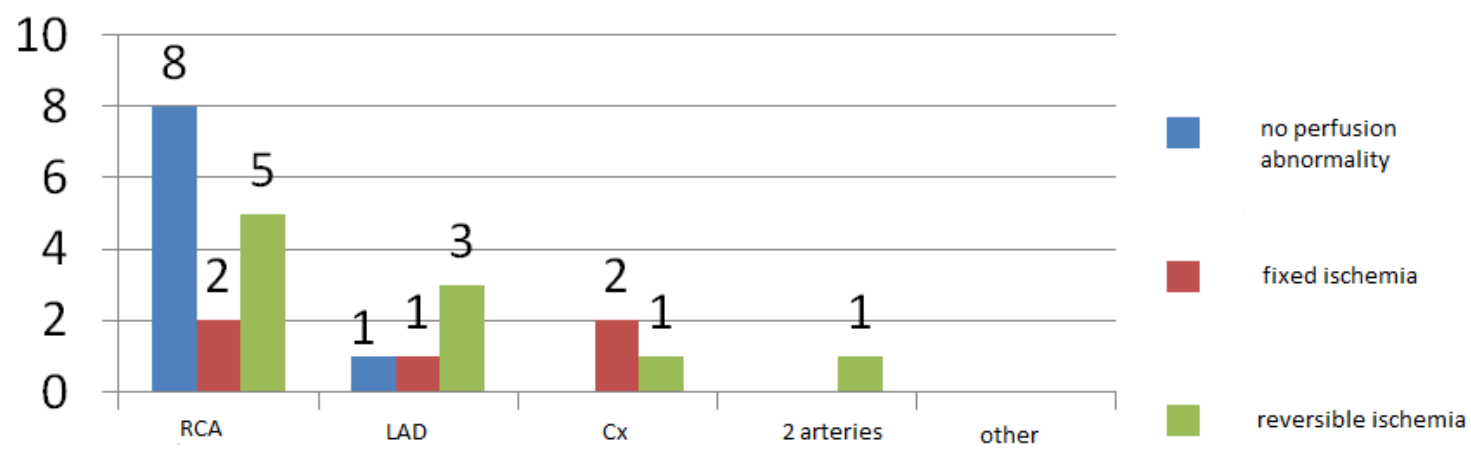

Chart 3. Ischemia characterization in women with CTO part 1.

Number of patients with normal perfusion or ischemia $\leq 5 \% ;>5 \%$ fixed only ischemia and $>5 \%$ reversible ischemia. 


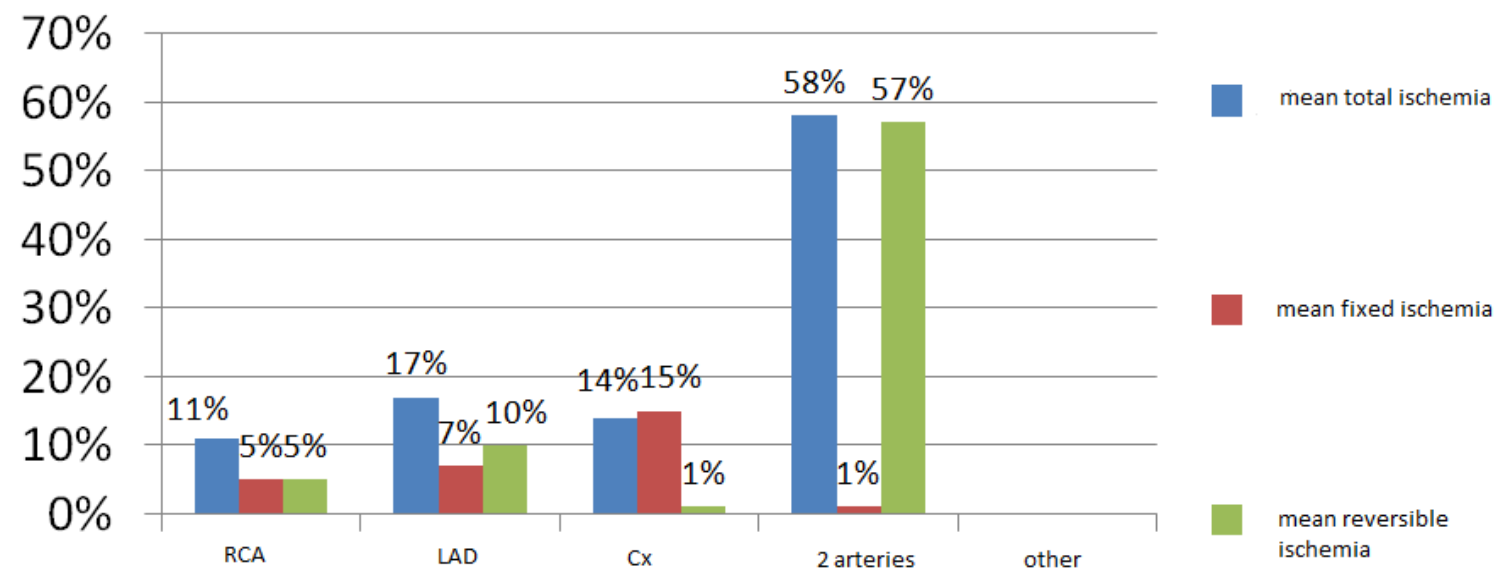

Chart 4. Ischemia characterization in women with CTO part 2.

Ischemia percentage in particular coronary artery occluded.

Most important findings:

- $\quad$ Left ventricle enlargement was found in 6 patients $(25 \%)$; the greatest enlargement was found in case of RCA CTO and CTO of two arteries,

- In case of RCA CTO reversible ischemia was more commonly found in women than in mean;

- $\quad$ Still, in case of RCA CTO most commonly normal perfusion or insignificant ischemia were found;

- Similarly to men, in women LAD CTO was most commonly associated with reversible ischemia.

\section{Discussion}

In the group of patients with perfusion scintigraphy of the heart, CTO also occurred mainly in RCA (62\% in total, 57\% in men, 67\% in women). Similarly, LAD was the second most frequent (15\% in total, $13 \%$ in men, $17 \%$ in women), followed by $\mathrm{Cx}$ (13\% in total, $18 \%$ in men, $8 \%$ in women). According to the Lei Guo study, CTO was most commonly found in the right coronary artery (44.2\%), less frequently in the descending anterior left artery $(32.7 \%)$ and the peripheral left artery (23.1\%) [11]. This is also confirmed by T. Teramoto's study, whose analysis also revealed the dominance of CTO in the anterior descending artery over the remaining coronary arteries [12].

Similar results were presented in M. Mączynski's analysis. In nearly half of the cases the dominant location of CTO is RCA (49.1\%), LAD (31.4\%) and Cx (19.5\%) were classified on the following positions [13].

SPECT examination allows to evaluate ejection fraction of the left ventricle. In the studied group it was $74 \%$ on average in women and $61 \%$ in men. According to B. Kałuza, the mean ejection fraction is classified at the level of $46.8 \pm 10.7 \%$. 
It also allows to obtain data on global and regional perfusion and function parameters such as: ejection fraction, wall thickening and motion, left ventricle end systolic and end systolic volumes [6].

\section{Study limitations}

The study has limited value since it does not include patients history covering previous myocardial infarction or invasive treatment of coronary artery disease. The data was not always available in the presented group.

Still, information about normal perfusion or reversible ischemia clearly indicate when invasive treatment should be considered and presented results clearly show, that in many patients it is unnecessary.

\section{Conclusions}

PCI CTO treatments are very demanding in terms of staff skills and equipment used. In leading centers, the effectiveness is more than $90 \%$. One quarter of patients suffer from chronic coronary artery occlusion accompanied by coronary artery atherosclerosis. Technical difficulties and lower effectiveness of PCI procedures in this group require different treatment than in patients with incomplete coronary artery occlusion. The PCI method is used in less than half of the patients and $20 \%$ of them are conservatively treated and $30 \%$ are directed to cardiac revascularization (CABG). In the case of centers not specialized in PCI CTO, the number of successive interventions decreases significantly. The appearance of CTO of coronary arteries is in most cases chronic, asymptomatic, and in coronary angiography it is manifested by well-developed side circulation, which maintains a sufficient level of myocardial blood circulation, which causes controversy in the legitimacy of invasive treatment. The occlusal vessel usually occurs in the post-infarction area, which further undermines the legitimacy of this type of therapy. The studies do not show the advantages of invasive treatment in a few years perspective. Other studies indicate that proper CTO recanalization often significantly improves the patient's comfort and condition, assuming that the clogged vessel supplies an important part of the vital corpus of the heart, leading to extensive ischaemia of the said area. Well-developed side circulation, in most cases does not ensure full blood circulation of the heart tissues and does not protect against ischemia. Therefore, an effective PCI treatment, by reducing the area of ischaemia in the most efficient areas, may reduce the associated negative phenomena, such as angina pectoris and ventricular arrhythmias.

\section{References}

1. Stone GW, Kandzari DE, Mehran R, Colombo A, Schwartz RS, Bailey S, Moussa I, Teirstein PS, Dangas G, Baim DS, Selmon M, Strauss BH, Tamai H, Suzuki T, Mitsudo K, Katoh O, Cox DA, Hoye A, Mintz GS, Grube E, Cannon LA, Reifart NJ, Reisman M, Abizaid A, Moses JW, Leon MB, Serruys PW. Percutaneous recanalization of chronically occluded coronary arteries: a consensus document: part I. [Circulation]. 2005; 112 (15): 2364-2372.

2. Stone GW, Reifart NJ, Moussa I, Hoye A, Cox DA, Colombo A, Baim DS, Teirstein PS, Strauss BH, Selmon M, Mintz GS, Katoh O, Mitsudo K, Suzuki T, Tamai H, Grube E, 
Cannon LA, Kandzari DE, Reisman M, Schwartz RS, Bailey S, Dangas G, Mehran R, Abizaid A, Moses JW, Leon MB, Serruys PW. Percutaneous recanalization of chronically occluded coronary arteries: a consensus document: part II. [Circulation], 2005; 112 (16): 2530-2537.

3. Schumacher SP, Stuijfzand WJ, Opolski MP, van Rossum AC, Nap A, Knaapen, P. Percutaneous coronary intervention of chronic total occlusions: When and how to treat. [Cardiovascular revascularization medicine: including molecular interventions] 2018. DOI: 10.1016/j.carrev.2018.07.025.

4. Celik T; Ozturk C; Balta S; Iyisoy A. The best treatment option in the management of patients with chronic total occlusion of a single coronary artery: Debate continues. [International journal of cardiology], 2016. 214, s. 79-80. DOI: 10.1016/j.ijcard.2016.03.145.

5. Kobylecka M. Miejsce badań izotopowych we współczesnej diagnostyce kardiologicznej. [Choroby Serca i Naczyń], 2015; 12 (5), s. 318-323, [Cited: 03.03.2020]. https://journals.viamedica.pl/choroby_serca_i_naczyn/article/download/43803/30101.

6. Klocke FJ, Baird MG, Lorell BH et al. American College of Cardiology, American Heart Association Task Force on Practice Guidelines, American Society of for Nuclear Cardiology. ACC/AHA/ASNC guideli-nes for the clinical use of cardiac radionuclide imaging: a report of the American College of Cardiology/American Heart Association Task Force on Practice Guidelines. [Circulation], 2003; 108: 1404-1418.

7. Joyal D, Afilalo J, Rinfret S. Effectiveness of recanalization of chronic total occlusions: a systematic review and meta-analysis. [American heart journal], 2010; 160 (1), s. 179-187. DOI: 10.1016/j.ahj.2010.04.015.

8. Parol G, Kobylecka M, Bakoń L. Nieinwazyjna diagnostyka choroby niedokrwiennej serca- którą opcje diagnostyczną wybrać? [Diagnostyka Kardiologiczna, Folia Cardiologica ], 2014; Via Medica. 9 (2): 197-204. ISSN 2353-7752.

9. Yang JH, Kim BS, Jang WJ, Ahn J, Park TK, Song YB et al. Optimal Medical Therapy vs. Percutaneous Coronary Intervention for Patients With Coronary Chronic Total Occlusion - A Propensity-Matched Analysis. [Circulation journal : official journal of the Japanese Circulation Society], 2016; 80 (1), s. 211-217.

10. de Labriolle A, Bonello L, Roy P. Comparison of safety, efficacy, and outcome of successful versus unsuccess-ful percutaneous coronary intervention in "true" chronic total occlusions. [Am J Cardiol], 2008; 102: 1175-1181.

11. Gu, L, Zhong, L, Chen K, Wu J, Huang RC. Long-term clinical outcomes of optimal medical therapy vs. successful percutaneous coronary intervention for patients with coronary chronic total occlusions, [Hellenic journal of cardiology : HJC = Hellenikekardiologikeepitheorese], 2018; 59 (5), 281-287.

12. Teramoto T, Tsuchikane E, Matsuo H, et al. Initial Success Rate of Percutaneous Coronary Intervention for Chronic Total Occlusion in a Native Coronary Artery Is Decreased in Patients Who Underwent Previous Coronary Artery Bypass Graft Surgery. [JACC Cardiovasc Interv], 2014; 7(1): 39-46.

13. Mączyński M. Wpływ rekanalizacji przewlekle niedrożnej tętnicy wieńcowej na rokowanie pacjentów z chorobą niedokrwienną serca, [Rozprawa doktorska. I Klinika Kardiologii Uniwersytetu Medycznego im. Karola Marcinkowskiego w Poznaniu, Uniwersytet Medyczny im. Karola Marcinkowskiego w Poznaniu], 2014; Poznań, 37. 